\title{
PENGARUH FINANCIAL SOCIALIZATION, FINANCIAL KNOWLEDGE, FINANCIAL EXPERIENCE TERHADAP FINANCIAL MANAGEMENT BEHAVIOR DENGAN LOCUS OF CONTROL SEBAGAI VARIABEL MEDIASI PADA PENGGUNA PAYLATER
}

\author{
Vicky Pradita Dewanti \\ Universitas Negeri Surabaya \\ vickypradita4@gmail.com \\ Nadia Asandimitra \\ Universitas Negeri Surabaya \\ nadiaharyono@unesa.ac.id
}

Abstract

The research of this study investigates financial management behaviour among the user of the Paylater in Surabaya. It also analyzes the relationship between financial socialization, financial knowledge, financial experience, and locus of control as a mediating variable. This research is conclusive causality, used purposive sampling and snowball sampling techniques. The total number of respondents obtained was 234 respondents by distributing questionnaires online. Data analyzed using the Structural Equation Modeling (SEM) analysis technique in the AMOS software. The results show that financial knowledge significantly impacts financial management behaviour, while financial socialization, financial experience, and locus of control do not affect financial management behaviour. The mediation testing result shows that locus of control cannot mediate between financial knowledge and financial management behaviour. Because the sample dominant is the student and age range between 15 and 24, almost all of them still have income from their parents, so they can not manage financial independence to the greatest extent and do not have much experience related to finance. It was also caused by female respondents who often engage in impulsive buying. This study could be helpful to references for various parties, especially Paylater users, to be responsible for making financial decisions and wise in managing their finances.

Keywords: financial experience; financial knowledge; financial management behavior; financial socialization; locus of control.

\section{PENDAHULUAN}

Era digitalisasi dengan perkembangan teknologi dan informasi yang cepat saat ini, berdampak pada bidang perekonomian salah satunya dilihat dari sistem transaksi yang mengalami pergeseran alat transaksi tunai menjadi non-tunai atau transaksi uang elektronik yang lebih mempermudah dalam proses bertransaksi (bi.go.id, 2020). Berdasarkan data Bank Indonesia (BI) tahun 2019, penggunaan uang elektronik semakin meningkat sebanyak 31 kali lipat dalam kurun waktu 10 tahun, hal ini terjadi karena besarnya jumlah penduduk Indonesia, tingkat konsumsi dan literasi keuangan masyarakat yang semakin meningkat (Kusnandar, 2019). Peningkatan konsumsi masyarakat dapat dilihat dari meningkatnya persentase Marginal Property to Consum (MPC) menurunnya persentase Marginal Property to Safety (MPS) dalam 3 tahun terakhir (kompas.com, 2015).

Uang elektronik dibagi menjadi dua kelompok yaitu e-money dan e-wallet, e-money yaitu uang elektronik berbasis chip dengan media kartu dan untuk proses transaksi dilakukan secara offline, sedangkan $e$-wallet merupakan dompet elektronik dengan media aplikasi yang dapat diakses lewat ponsel dan proses transaksi dilakukan secara online (bi.go.id, 2020). E-wallet mulai disukai dan diterima oleh masyarakat semenjak banyak perusahaan beromba mengeluarkan dan mengembangkan fitur yang ada di dalamnya salah satunya adalah paylater, yaitu sistem cicilan kartu kredit digital, fitur ini menawarkan kepada masyarakat agar dapat memenuhi kebutuhannya seperti berbelanja, transfer, memesan makanan hingga travelling tanpa harus menunggu mempunyai uang yang cukup sehingga sangat membantu penggunanya dalam memenuhi kebutuhan, hal ini menjadikan paylater menjadi salah satu tren yang menarik perhatian masyarakat jaman sekarang (Rohmatillah, 2019). 
Vicky Pradita Dewanti \& Nadia Asandimitra. Pengaruh Financial Socialization, Financial Knowledge, Financial Experience terhadap Financial Management Behavior dengan Locus of Control sebagai Variabel Mediasi pada Pengguna Paylater

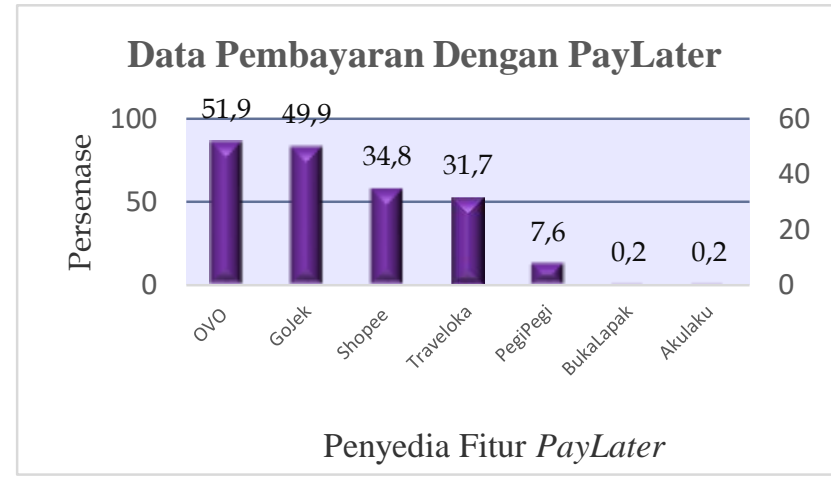

Sumber: Dailysocial.id (2019, data diolah)

\section{Gambar 1. DATA PEMBAYARAN DENGAN PAYLATER}

Gambar 1 menunjukkan data pembayaran menggunakan paylater tahun 2019 terdapat empat $e$-wallet penyedia fitur paylater yang memiliki persentase penggunaan terbesar di antara paylater lain, yaitu OVO paylater $51,9 \%$, Gojek paylater $49,9 \%$, Shopee paylater $34,8 \%$ dan Traveloka paylater $31,7 \%$ (Lidwina, 2019). Menurut data Bank Indonesia (BI) pada triwulan pertama tahun 2019 pengguna uang elektronik di Kota Surabaya terbesar di Jawa Timur, yaitu sekitar 292.000 orang, pada posisi kedua adalah Kabupaten Jember dengan pengguna uang elektronik sebesar 258.000 orang (Wahyunik, 2019). Hal ini mengindikasikan bahwa pengguna e-money di Kota Surabaya merupakan yang paling tinggi di wilayah Jawa Timur.

Kemudahan yang ditawarkan fitur paylater sangat berguna apabila dipakai dengan bijak karena dapat memenuhi kebutuhan sehari-hari, membantu dalam hal mengelola keuangan serta mempermudah proses transaksi, namun pengguna paylater juga perlu mengetahui kelebihan dan kekurangan fitur terlebih dahulu karena dapat menggangu kestabilan financial dan adanya risiko terhadap pola konsumsi yang tidak bertanggung jawab (Rohmatillah, 2019). Pengelolaan keuangan sangat diperlukan bagi pengguna paylater agar terhindar dari jerat hutang dan cicilan yang menumpuk (Rohmatillah, 2019). Oleh sebab itu perilaku pengelolaan keuangan pada pengguna paylater merupakan masalah yang menarik untuk diteliti dengan melihat berbagai sudut pandang ilmu pengetahuan, salah satunya adalah ilmu manajemen.

Perilaku pengelolaan keuangan (financial management behavior) mengacu pada tingkat kemampuan keuangan pengelolaan harian pribadi seseorang mulai dari perencanaan, penganggaran, pemeriksaan, pengeloaan, penyimpanan, pencarian, serta pengendalian (Kholilah \& Iramani, 2013). Adanya variabel yang dapat memengaruhi financial management behavior seseorang misalnya variabel financial socialization, , financial experience (Safitri \& Kartawinata, 2020) dan variabel financial knowledge, dan locus of control (Rahmawati \& Asandimitra, 2020).

Faktor pertama adalah financial socialization merupakan suatu proses seseorang dalam mendapatkan sikap, informasi serta keterampilan yang digunakan untuk meningkatkan kompetensi seseorang dalam financial markets (Ward, 1978). Ameliawati \& Setiyani (2018) dan Safitri \& Kartawinata (2020) menerangkan financial socialization memengaruhi financial management behavior, namun Sobaya et al. (2016) mengungkapkan financial socialization tidak memengaruhi perilaku pengelolaan keuangan, selain itu penelitian Ramadhan \& Asandimitra (2019) juga menunjukkan financial socialization agent secara spesifik pada primary agent tidak memengaruhi financial management behavior.

Faktor kedua yaitu pengetahuan keuangan atau financial knowledge merupakan tingkat pengetahuan individu dan penguasaan terhadap hal-hal seputar keuangan, alat keuangan, serta keterampilan keuangan (Kholilah \& Iramasni, 2013). Penelitian yang dilakukan Rahmawati \& Asandimitra (2020), 
Yanuar \& Asandimitra (2019), Pradiningtyas \& Lukiastuti (2019), dan Mien \& Thao (2006) menyebutkan seseorang dengan pengetahuan keuangan luas akan memengaruhi perilaku pengelolaan keuangannya. Namun penelitian Kholilah \& Iramani (2013) dan Prihartono \& Asandimitra (2018) mendapatkan hasil yang berbeda yaitu tidak adanya pengaruh pengetahuan keuangan terhadap financial management behavior.

Faktor ketiga yaitu pengalaman keuangan (financial experience) yaitu kejadian maupun pengalaman masa lalu yang dijalani, dirasakan dan ditanggung seputar keuangan baik pengalaman lama maupun baru (Pritazahara \& Sriwidodo, 2015). Darmawan et al. (2018) menunjukkan financial experience memengaruhi perilaku pengelolaan keuangan, sehingga seseorang yang ingin meningkatkan kemampuannya dalam mengelola keuangannya maka harus menambah pengalaman terkait keuangan. Hasil tersebut didukung Purwidianti \& Tubastuvi (2019). Safitri \& Kartawinata (2020) memiliki hasil penelitian yang bertolak belakang yaitu financial experience tidak memengaruhi financial management behavior.

Faktor keempat adalah locus of control mewakili peristiwa dalam diri seseorang melalui pengendalian diri yang akan berdampak pada pandangan di masa mendatang, sehingga seseorang dapat mengendalikan keinginan dan mementingkan kebutuhan. Penelitian Pradiningtyas \& Lukiastuti (2019) memperoleh hasil bahwa locus of control memengaruhi perilaku pengelolaan keuangan. Berbeda dari Mien \& Thao (2006); Prihartono \& Asandimitra (2018); Ida \& Dwinta (2010); Rahmawati \& Asandimitra (2020) dan Yanuar \& Asandimitra (2019) mengatakan locus of control tidak memengaruhi perilaku pengelolaan keuangan.

Locus of control juga merupakan mediasi financial knowledge terhadap financial management behavior, untuk mengetahui apakah terdapat pengaruh tidak langsung dari hubungan tersebut. Kontrol diri diharapkan dapat memberi seseorang arah dalam menjalankan pengelolaan keuangannya dengan lebih bijak. Penelitian terdahulu oleh Pradiningtyas \& Lukiastuti (2019) mendapatkan hasil bahwa financial knowledge dan locus of control memengaruhi financial management behavior bahkan dalam penelitian tersebut mendapatkan hasil locus of control dapat memediasi hubungan pengetahuan keuangan dengan perilaku pengelolaan keuangan. Namun berbeda dengan Mien \& Thao (2006) dan Rahmawati \& Asandimitra (2020). yang menyatakan bahwa locus of control tidak dapat memediasi hubungan pengetahuan keuangan dengan perilaku pengelolaan keuangan.

Penelitian ini bertujuan untuk menguji pengaruh financial socialization, financial knowledge, financial experience terhadap financial management behavior dengan locus of control sebagai variabel mediasi pada pengguna paylater di Surabaya.

\section{KAJIAN PUSTAKA DAN PENGEMBANGAN HIPOTESIS}

\section{Theory of Planned Behavior}

Ajzen (2002) menjelaskan teori perilaku terencana merupakan teori pembelajaran mengenai studi perilaku seseorang yang dilakukan dengan dasar niat untuk mencapai maksud dan tujuan tertentu. Berdasarkan teori ini latar belakang merupakan faktor yang sangat berpengaruh dalam memprediksi perilaku seseorang, faktor pertama adalah personal meliputi cara bersikap, emosi, kecerdasan, kepribadian dan nilai hidup, faktor kedua adalah informasi meliputi pengetahuan, pengalaman, berita di media, faktor ketiga adalah sosial meliputi usia, suku, gender, pendidikan, etnis, agama dan penghasilan seseorang (Ajzen, 2005).

\section{Social Learning Theory}

Social learning theory menjelaskan kepribadian akan mencerminkan bagaimana individu tersebut berinteraksi dengan lingkungan sekitar (Rotter, 1966). Social learning theory adalah konsep teori dimana perilaku seseorang ditentukan oleh efek penguatan sebagai latar belakang serta menjadi penguat terhadap kepercayaan seseorang bahwa pengalaman di masa lalu adalah peluang bagi individu tersebut untuk memiliki pandangan positif maupun negatif di masa yang akan datang (Rotter, 
Vicky Pradita Dewanti \& Nadia Asandimitra. Pengaruh Financial Socialization, Financial Knowledge, Financial Experience terhadap Financial Management Behavior dengan Locus of Control sebagai Variabel Mediasi pada Pengguna Paylater

1966). Adanya empat faktor penentu perilaku seseorang, yaitu harapan (dirinya percaya dapat berperilaku pada situasi yang sudah diprediksikan sebelumnya), nilai penguatan (pilihan satu penguatan dengan lainnya), potensi perilaku (adanya kemungkinan perilaku yang mungkin terjadi pada situasi tertentu), dan situasi psikologis yang didasari reaksi diri seseorang atas lingkungan (Rotter, 1966).

\section{Financial Management Behavior}

Financial management behavior adalah proses pembentukan karakter keuangan seseorang dengan cara menumbuhkan perilaku pengelolaan pribadi seseorang (Sina \& Noya, 2012). Perilaku pengelolaan keuangan dapat melihat sejauh mana seseorang berhasil membuat rencana keuangannya. Perilaku pengelolaan keuangan juga berkaitan dengan bagaimana seseorang dapat melaksanakan tanggung jawabnya dan bagaimana cara mengelola keuangannya sendiri (Rizkiawati \& Asandimitra, 2018). Financial management behavior dapat dinilai melalui lima indikator yaitu pengontrolan pengeluaran, pembuatan rencana keuangan di masa depan, pembayaran tagihan tepat waktu, penyimpanan uang dan penyediaan uang (Ida \& Dwinta, 2010).

\section{Financial Socialization}

Financial socialization adalah lingkungan sosial seseorang baik internal maupun eksternal dapat memicu proses seseorang memperoleh keterampilan, pengetahuan dan sikap keuangan (Albeerdy \& Gharleghi, 2015). Cara bersikap, keterampilan serta pengetahuan seseorang tentang berbagai hal keuangan dapat dipengaruhi oleh orang-orang yang berinteraksi dengan lingkungan sekitarnya (Churchill \& Moschis, 1979). Sundarasen et al. (2016) mengungkapkan agen sosial keuangan yakni pendidikan (formal maupun non formal), media (cetak dan elektronik), orang tua (ayah dan ibu) dan pertemanan, merupakan indikator dari sosialisasi keuangan.

\section{Financial Knowledge}

Financial knowledge adalah keahlian yang dimiliki seseorang untuk mengumpulkan, mencerna serta melakukan evaluasi terkait informasi yang sesuai sebagai dasar pengambilan keputusan yang akan dibuat, dengan mempertimbangkan akibat yang akan ditimbulkan (Mason \& Wilson, 2000). Seseorang dikatakan memiliki financial knowledge apabila dapat memahami, menguasai serta berpengetahuan luas tentang segala hal terkait keuangan. Seseorang perlu meningkatkan keterampilan keuangan dan pembelajaran lebih lanjut mengenai financial tools untuk meningkatkan pengetahuan terkait keuangan (Ida \& Dwinta, 2010). Indikator digunakan antara lain pengetahuan tentang suku bunga, kredit, pengelolaan keuangan, investasi serta pemahaman terkait laporan keuangan pribadi (Ida \& Dwinta, 2010).

\section{Financial Experience}

Financial experience merupakan media pembelajaran bagi seseorang dalam pengelolaan keuangannya, financial experience adalah peristiwa yang dialami, dirasakan, dijalani, ditanggung terkait keuangan yang pernah dialami seseorang baik peristiwa lama maupun peristiwa baru (Safitri \& Kartawinata, 2020). Pengalaman keuangan dapat dicontohkan seperti merencanakan investasi, pendaftaran asuransi, pengajuan kredit di bank dan lain sebagainya. Seseorang yang memiliki peristiwa dan pengalaman masa lalu terkait keuangan yang pernah dihadapi, maka seseorang akan mampu menentukan perilaku keuangan dalam melatih keterampilan pengelolaan keuangan di masa depan (Safitri \& Kartawinata, 2020). Indikator yang digunakan adalah pengalaman terkait perbankan, produk asuransi, dana pensiun, pegadaian dan spasar modal (Purwidianti \& Mudjiyanti, 2016).

\section{Locus of Control}

Menurut Prihartono \& Asandimitra (2018), locus of control merupakan keyakinan yang dimiliki seseorang terhadap kemampuan mengontrol diri melalui pandangan peristiwa yang pernah dialami dengan didasari oleh faktor pengendali dalam diri dengan pemilihan skala prioritas kebutuhan untuk tindakan yang dilakukan karena menjadi penentu baik kegagalan maupun keberhasilannya. Jika seseorang dapat mengendalikan diri sendiri diharapkan dapat memiliki pandangan terhadap masa akan datang sehingga lebih mengutamakan kebutuhan daripada keinginnya (Rotter, 1966). Terdapat tujuh 
indikator dalam menilai locus of control seseorang antara lain, bisa memecahkan masalah sendiri, mendapatkan dorongan lingkungan sekitar, melakukan semua hal yang ada dipikiran, mempertimbangkan masa depan sebagai dampak perilaku sekarang, merasa optimis, memiliki kontrol diri, mengubah hal-hal penting yang terjadi (Ida \& Dwinta, 2010).

\section{Hubungan antar Variabel}

Pengaruh financial socialization atas perilaku pengelolaan keuangan dijelaskan dalam theory of planned behavior, yaitu norma subjektif dilihat dari variabel sosialisasi keuangan yang berkaitan dengan adanya pandangan serta dukungan orang lain dapat memengaruhi penerapan perilaku tertentu (Ajzen, 1991). Lingkungan sosial yang dihadapi kerap kali menjadi pembelajaran untuk mengasah keterampilan dan mengelola keuangan, agar seseorang dapat membuat keputusan yang tepat. Jika seseorang memiliki financial socialization yang baik maka perilaku pengelolaan keuangan juga akan meningkat begitupun sebaliknya (Safitri \& Kartawinata, 2020). Hal serupa ditunjukkan dalam penelitian Ameliawati \& Setiyani (2018). Sobaya et al. (2016) menunjukkan tidak terdapat pengaruh variabel financial socialization terhadap financial management behavior. Selain itu, Ramadhan \& Asandimitra (2019) menunjukkan bahwa financial socialization agent dalam hal ini secara spesifik pada primary agent tidak memengaruhi financial management behavior.

H1: Terdapat pengaruh financial socialization terhadap financial management behavior pada pengguna paylater di Surabaya.

Pengaruh pengetahuan keuangan terhadap financial management behavior juga didasari theory of planned behavior, yaitu niat dan tujuan merupakan penyebab dari seseorang berperilaku dengan beberapa faktor yang menjadi latar belakang salah satunya informasi yang menjadi sumber pengetahuan seseorang (Ajzen, 2005). Yanuar \& Asandimitra (2019) menyatakan terdapat pengaruh antara financial knowledge terhadap financial management behavior, maka seseorang yang mempunyai pengetahuan luas terkait keuangan dapat meningkatkan kemampuannya dalam mengelola keuangan. Hasil ini sejalan dengan Rahmawati \& Asandimitra (2020), Pradiningtyas \& Lukiastuti (2019), dan Mien \& Thao (2006). Hasil ini bertentangan dengan penelitian Rizkiawati \& Haryono (2018) yang menyatakan bahwa financial knowledge tidak berpengaruh terhadap perilaku pengelolaan keuangan didukung oleh Prihartono \& Asandimitra (2018); dan Kholilah \& Iramani (2013).

H2: Terdapat pengaruh financial knowledge terhadap financial management behavior pada pengguna paylater di Surabaya.

Berdasarkan theory of planned behavior, pengalaman masa lalu seseorang akan mencerminkan sikap seseorang dimasa yang akan datang (Ajzen, 2005). Hal tersebut akan menjadi dasar pengaruh financial experience terhadap financial management behavior. Seseorang yang memiliki pengalaman keuangan dapat belajar dari kejadian di masa lalu untuk mengelola keuangan pribadi dikemudian hari, sehingga seseorang dengan financial experience yang cukup akan memiliki perilaku lebih bijak dibanding seseorang dengan pengalaman keuangan yang minim dalam hal pengelolaan keuangnnya (Ameliawati \& Setiyani, 2018). Penelitian Purwidianti \& Tubastuvi (2019) menyatakan tidak terdapat pengaruh financial experience terhadap financial management behavior. Hal tersebut didukung oleh Darmawan et al. (2018). Namun Safitri \& Kartawinata (2020) memiliki hasil penelitian yang bertolak belakang yaitu financial experience tidak signifikan terhadap financial management behavior.

H3: Terdapat pengaruh financial experience terhadap financial management behavior pada pengguna paylater di Surabaya.

Social learning theory menjadi dasar pengaruh locus of control dengan financial management behavior yaitu perilaku seseorang bukan hanya dipengaruhi oleh lingkungan sekitar namun juga ditentukan oleh proses dari dalam diri individu itu sendiri (Rotter, 1966). Perilaku pengelolaan keuangan akan meningkat ketika seseorang dapat mengontrol dirinya sendiri untuk membelanjakan uang sesuai keperluan dan kebutuhannya saja (Rizkiawati \& Asandimitra, 2018). Penelitian Kholilah 
Vicky Pradita Dewanti \& Nadia Asandimitra. Pengaruh Financial Socialization, Financial Knowledge, Financial Experience terhadap Financial Management Behavior dengan Locus of Control sebagai Variabel Mediasi pada Pengguna Paylater

\& Iramani (2013) dan Pradiningtyas \& Lukiastuti (2019) telah membuktikan locus of control mempunyai pengaruh signifikan terhadap financial management behavior. Hal ini dapat diartikan, pengelolaan keuangan seseorang akan semakin meningkat jika seseorang mampu mengendalikan dirinya sendiri dari keinginan dan lebih mengutamakan kebutuhan (Kholilah \& Iramani, 2013). Tetapi Prihartono \& Asandimitra (2018) mengatakan locus of control tidak memengaruhi financial management behavior, didukung oleh Ida \& Dwinta (2010), Rahmawati \& Asandimitra (2020), dan Yanuar \& Asandimitra (2019).

H4: Terdapat pengaruh locus of control terhadap financial management behavior pada pengguna paylater di Surabaya.

Pengetahuan keuangan seseorang akan meningkat jika memiliki rasa tanggung jawab atau kontrol atas dirinya (Kholilah \& Iramani, 2013). Locus of control diharapkan bisa mengarahkan seseorang untuk mengelola keuangannya dengan lebih bijak. Perilaku pengelolaan keuangan akan semakin meningkat jika seseorang memiliki pengetahuan keuangan serta didampingi dengan kontrol diri yang baik (Kholilah \& Iramani, 2013). Penelitian Pradiningtyas \& Lukiastuti (2019) juga menyatakan bahwa locus of control berhasil memediasi pengetahuan keuangan terhadap perilaku pengelolaan keuangan. Akan tetapi, Rahmawati \& Asandimitra (2020) dan Mien \& Thao (2006) menyatakan kontrol diri tidak dapat memediasi pengaruh antara pengetahuan keuangan terhadap perilaku pengelolaan keuangan.

H5: Terdapat pengaruh financial knowledge terhadap financial management behavior dengan locus of control sebagai mediasi pada pengguna paylater di Surabaya.

Berdasarkan hipotesis yang telah dipaparkan, model penelitian dapat dilihat pada Gambar 2.

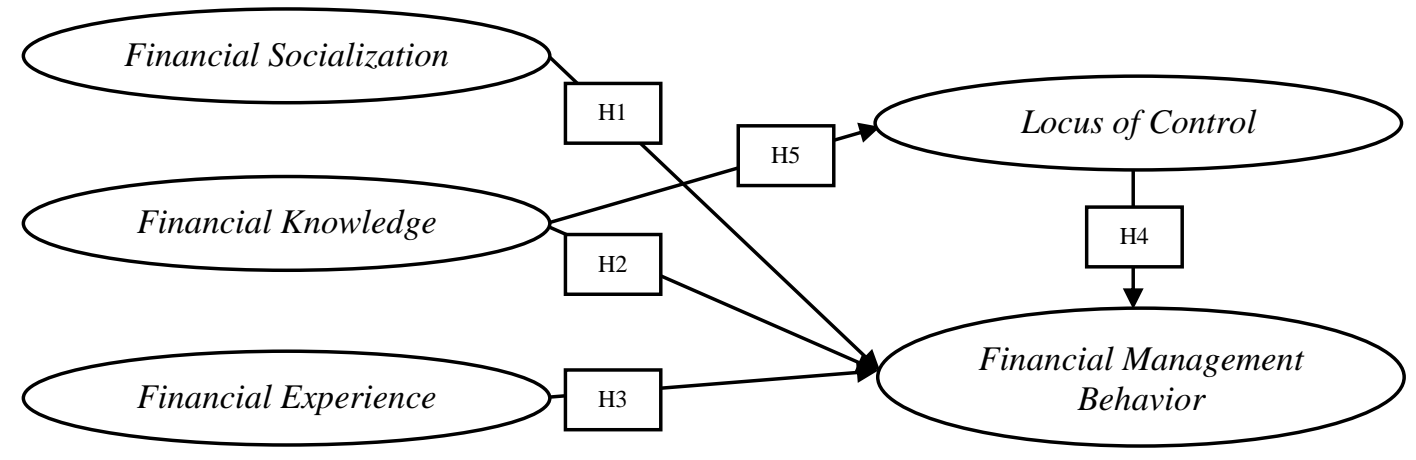

Gambar 2. MODEL PENELITIAN

\section{METODE PENELITIAN}

Ada tiga variabel dependen dalam penelitian ini yaitu financial socialization, financial knowledge dan financial experience, satu variabel independen yaitu financial management behavior, dan variabel mediasi yaitu locus of control. Jenis penelitian konklusif kausalitas, jenis data kuantitatif serta data primer. Masyarakat pengguna paylater di Surabaya sebagai populasi serta teknik purposive sampling dan snowball sampling untuk metode pengambilan sampel, dengan cara menyebarkan kuesioner online kepada responden. Kriteria responden adalah masyarakat Kota Surabaya, memiliki dan aktif menggunakan fitur paylater yang menjadi fokus utama yaitu Shopee paylater, Ovo paylater, Gojek paylater. Analisis Structural Equation Modeling (SEM) dengan software AMOS sebagai metode analisis data. Jawaban dari pernyataan yang telah diisi oleh responden diukur menggunakan skala likert dengan skor 1 sampai 4, skor pada masing masing indikator variabel ditotal dan dirata-rata. Rata-rata tersebut digunakan untuk melihat bobot dari jawaban seluruh responden dengan dasar three box method. Tahapan uji pertama adalah uji asumsi dengan uji outlier serta uji normalitas, dari 234 
data yang memenuhi kriteria responden yang diuji terdapat 35 data yang harus dioutlier atau dihilangkan sehingga data yang digunakan dalam pengujian selanjutnya adalah 199. Tahap kedua adalah untuk mengetahui apakah data sudah valid dan reliabel dengan uji validitas dan uji reliabilitas. Selanjutnya untuk melihat kelayakan model penelitian dilakukan uji kelayakan model dengan melihat nilai goodness of fit. Setelah model dinyatakan layak baru dilakukan uji hipotesis serta uji mediasi mengguakan sobel test untuk mengetahui hasil dalam penelitian.

\section{HASIL DAN PEMBAHASAN}

\section{Uji Outlier}

Uji outlier dapat dilihat melalui nilai mahalanobis distance, apabila data yang mempunyai nilai $\mathrm{p} 2<$ 0,002 maka data tersebut merupakan data yang outlier. Dalam pengujian ini ditemukan 35 data yang dinyatakan tidak lolos uji outlier dari 234 respoden. Data tersebut adalah responden dengan nomor 132, 232, 191, 147, 189, 191, 200, 79, 233, 107, 104, 85, 234, 103, 65, 122, 113, 128, 157, 109, 93, $164,162,195,139,95,64,96,141,50,34,97,99,116,124$. Sehingga data yang digunakan untuk penelitian adalah 199 data.

\section{Uji Normalitas}

Uji normalitas dapat dilihat dari assesment of normality yang terdapat pada output AMOS. Data normal merupakan data yang memenuhi syarat maximum likehood. Data dikatakan normal apabila nilai critical ratio diantara -2,58 sampai dengan 2,58. Berdasarkan uji normalitas, diketahui bahwa FMB1, FMB2, FMB5, FMB6, FS1, FS3, FK3, FK5, FE3, FE4, LOC1, LOC5, LOC6 dan LOC7 mempunyai nilai lebih dari $+-2,58$, hal ini berarti data harus dihapus karena tidak terdistribusi normal. Sedangkan untuk FMB3, FMB4, FMB7, FS2, FS4, FK1, FK2, FK4, FE1, FE2, FE5, LOC2, LOC3 dan LOC4 datanya terdistribusi normal.

\section{Uji Validitas}

Uji validitas dilakukan melalui dua cara yaitu uji Variance Extracted (AVE) dan uji discriminant validity dengan melihat nilai standardized regression weights. Hasil pengujian varians extracted $(A V E)$ menyatakan bahwa semua variabel penelitian dinyatakan valid karena nilai variabel financial management behavior, locus of control, financial socialization, financial knowledge, serta financial experience, melebihi angka 0,5 (>0,5). Dan dari hasil uji discriminant validity semua indikatorindikator penelitian dinyatakan valid karena nilai variabel dalam penelitian lebih tinggi dari nilai korelasi antar indikator.

\section{Uji Reliabilitas}

Uji reliabilitas dilakukan melalui uji Construct Reliability $(C R)$ dengan melihat nilai standardized regression weights. Hasil pengujian menunjukkan bahwa variabel financial knowledge, financial experience, dan locus of control dinyatakan reliabel karena semua nilai Construct Reliability $(C R)$ lebih dari 0,7. Sedangkan indikator pada variabel financial management behavior, financial socialization, berada pada angka $0,6-0,7$. Semua variabel dalam penelitian dapat digunakan sebagai alat ukur penelitian.

Tabel 1.

UJI GOODNESS OF FIT INDICES

\begin{tabular}{cccc}
\hline Goodness of Fit & Cut of Value & Nilai & Keterangan \\
\hline GFI & $>0,90$ & 0,952 & Baik \\
CMIN/Df & $<2,00$ & 1,231 & Baik \\
NFI & $>0,90$ & 0,927 & Baik \\
AGFI & $>0,90$ & 0,914 & Baik \\
RMSEA & $0,05-0,08$ & 0,035 & Marginal \\
TLI & $>0,90$ & 0,976 & Baik \\
\hline
\end{tabular}

Sumber: AMOS Output (data diolah) 
Vicky Pradita Dewanti \& Nadia Asandimitra. Pengaruh Financial Socialization, Financial Knowledge, Financial Experience terhadap Financial Management Behavior dengan Locus of Control sebagai Variabel Mediasi pada Pengguna Paylater

\section{Uji Kelayakan Model}

Uji kelayakan model dilihat melalui uji goodness of fit dengan melihat nilai GFI, CMIN/DF, NFI, AGFI, RMSEA, TLI, berdasarkan tabel 1, hasil goodnes of fit menunjukkan bahwa terdapat lima hasil yang baik (GFI, CMIN/DF, NFI, AGFI, TLI) sedangkan nilai RMSEA berada pada kategori marginal. Dapat diartikan model penelitian berada dikondisi yang baik maka dapat dilanjutkan untuk tahap uji hipotesis. Namun pada awal pengujian nilai GFI, CMIN/DF, NFI, AGFI, TLI belum memenuhi cut of value sehingga dilakukan modification indices dengan cara melihat nilai correlation error dan menghubungkan error dengan nilai terbesar untuk mencapai model fit. Maka setelah dilakukan uji kelayakan model menghasilkan model yang fit seperti yang dapat dilihat pada Gambar 3.

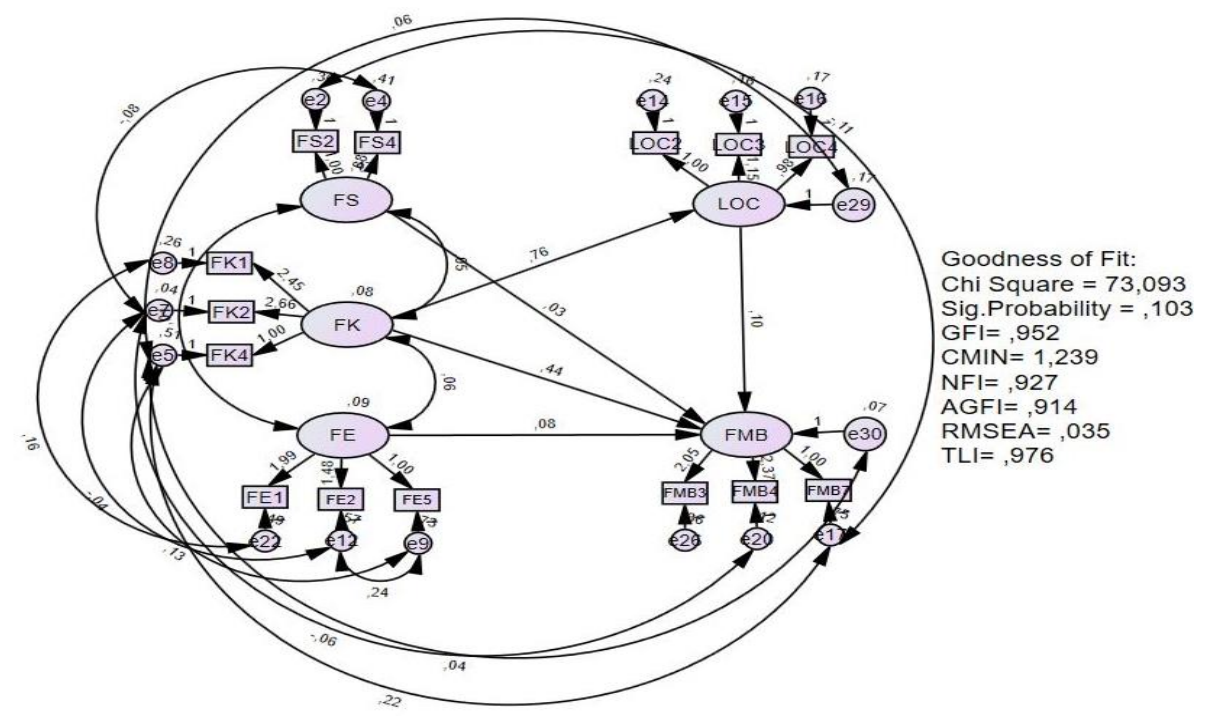

Sumber: Hasil olah data AMOS (data diolah)

\section{Gambar 3. MODEL AKHIR DIAGRAM JALUR}

\section{Uji Hipotesis}

Uji hipotesis dapat dilihat melalui nilai probabilitas signifikansi (p) dengan taraf signifikansi 0,05 dan dilihat melalui nilai critical ratio dengan taraf 2,00. Dapat dilihat pada tabel 2, H1 ditolah karena nilai P sebesar $0,508(\geq 0,05)$ dan nilai CR 0,663 $(\leq 2,00), \mathrm{H} 2$ dapat diterima karena nilai P adalah $0,013(\leq$ $0,05)$ dan nilai CR 2,494 ( $\geq 2,00)$, H3 ditolak karena P sebesar $0,618(\geq 0,05)$ dan nilai CR 0,498 ( $\leq$ 2,00), H4 ditolak karena P senilai $0,155(\geq 0,05)$ dan nilai CR 0,115 $(\leq 2,00)$.

Tabel 2.

HASIL UJI HIPOTESIS DAN MEDIASI

\begin{tabular}{clcccccc}
\hline Hipotesis & \multicolumn{1}{c}{ Variabel } & Estimate & S.E. & C.R. & P & $\begin{array}{c}\text { Test } \\
\text { Statistik }\end{array}$ & $\begin{array}{c}\text { p- } \\
\text { value }\end{array}$ \\
\hline H 1 & FS $\rightarrow$ FMB & 0,027 & 0,041 & 0,663 & 0,508 & & \\
H 2 & FK $\rightarrow$ FMB & 0,440 & 0,176 & 2,494 & 0,013 & & \\
H 3 & FE $\rightarrow$ FMB & 0,075 & 0,151 & 0,498 & 0,618 & & \\
H 4 & LOC $\rightarrow$ FMB & 0,097 & 0,068 & 1,421 & 0,155 & & \\
H 5 & FK $\rightarrow$ LOC $\rightarrow$ & & & & & 1,360 & 0,173 \\
\hline
\end{tabular}

Sumber: AMOS Output dan Sobel Test (data diolah)

\section{Uji Mediasi}

Sobel test digunakan untuk uji mediasi, mengetahui adanya pengaruh tidak langsung hubungan atar variabel yang dapat dilihat dari tabel 2. Uji mediasi digunakan untuk menguji H5 yaitu fiancial 
knowledge $\rightarrow$ locus of control $\rightarrow$ financial management behavior, namun dalam pengujian didapati H5 ditolak karena nilai P senilai 0,173 lebih dari 0,05.

\section{Uji Determinasi}

Analisis pengujian model pengukuran determinasi dilakukan dengan melihat nilai squared multiple correlation. Nilai $r$-square atau nilai estimate pada variabel financial management behavior adalah 0,288 , sehingga hasil pengujian dapat dinyatakan kontribusi financial socialization, financial knowledge, financial experience dan locus of control pada financial management behavior sebesar 0,288 atau $28,8 \%$, sedangkan 0,712 atau $71,2 \%$ dijelaskan oleh faktor di luar dari penelitian ini, seperti penelitian oleh Rahmawati \& Asandimitra (2020) yaitu variabel income, financial attitude serta penelitian Rizkiawati \& Asandimitra (2018) yaitu variabel jenis kelamin, usia, financial selfefficacy dan lain sebagainya.

\section{Pengaruh Financial Socialization terhadap Financial Management Behavior}

Financial socialization tidak memberikan pengaruh terhadap financial management behavior maka H1 penelitian tidak terbukti. Hasil ini menunjukkan bahwa responden dalam penelitian yaitu pengguna paylater di Surabaya cenderung tidak terpengaruh dengan agen-agen sosial dalam proses sosialisasi lingkungan baik internal maupun eksternal sehingga tidak berdampak pada sikap dan perilaku pengelolaan keuangan yang dilakukan. Hasil tersebut berbeda dengan theory of planned behavior, bahwa lingkungan sosial dapat memengaruhi niat atau tujuan perilakunya (Ajzen, 1991).

Hal ini dikarenakan tingkat financial socialization pada responden tinggi tetapi perilaku pengelolaan keuangan pada kategori sedang mengindikasikan bahwa tinggi dan rendahnya peranan sosialisasi dari agen-agen sosial belum tentu efektif dan berimplikasi dalam memberikan perspektif atau pandangan terhadap pengelolaan keuangan responden. Hal ini mendukung penelitian Sobaya et al. (2016) dan Ramadhan \& Asandimitra (2019) menunjukkan financial socialization agent secara spesifik pada primary agent tidak memberikan pengaruh pada financial management behavior.

\section{Pengaruh Financial Knowledge terhadap Financial Management Behavior}

Hasil penelitian mampu membuktikan $\mathrm{H} 2$ yang artinya financial knowledge memengaruhi financial management behavior. Hal ini membuktikan responden penelitian yaitu pengguna paylater di Surabaya dapat meningkatkan perilaku manajemen keuangan dengan memperbanyak pengetahuan tentang keuangan mereka. Sejalan dengan theory of planned behavior, informasi merupakan sumber pengetahuan bagi seseorang yang akan memengaruhi perilaku seseorang (Ajzen, 2005).

Hal ini karena $65,8 \%$ responden merupakan pelajar/mahasiswa, seseorang yang mempunyai pendidikan atau tingkat pengetahuan tinggi cenderung akan selalu memperhatikan serta waspada dengan masa depannya hal ini akan mendorong seseorang untuk lebih mencari tahu tentang istilah keuangan, penerapan kredit, pengelolaan aset, dan investasi sehingga dapat menentukan bagaimana perilaku manajemen keuangan dapat diterapkan dengan baik. Hasil ini mendukung penelitian yang dilakukan oleh Yanuar \& Asandimitra (2019); Rahmawati \& Asandimitra (2020); Pradiningtyas \& Lukiastuti (2019) dan Mien \& Thao (2006).

\section{Pengaruh Financial Experience terhadap Financial Management Behavior}

Hipotesis penelitian $\mathrm{H} 3$ ditolak karena hasil penelitian yaitu financial experience tidak terbukti memengaruhi financial management behavior. Hal tersebut menunjukkan bahwa responden dalam penelitian yaitu pengguna paylater di Surabaya cenderung tidak terbentuk dari peristiwa dan pengalaman keuangan masa lalu, sehingga tidak berdampak pada sikap dan perilaku pengelolaan keuangan di masa mendatang. Hal tersebut tidak sejalan dengan theory of planned behavior, dimana pengalaman merupakan salah satu aspek yang akan memengaruhi perilaku seseorang (Ajzen, 2005).

Hal ini terjadi berdasarkan hasil data penelitian, sebanyak 88,9\% dari responden masih berusia 15-24 tahun, dan 65,8\% merupakan pelajar/ mahasiswa, Jadi sebagian besar responden belum berada pada kondisi mandiri secara financial masih bergantung kepada orang tua dan responden masih berada 
Vicky Pradita Dewanti \& Nadia Asandimitra. Pengaruh Financial Socialization, Financial Knowledge, Financial Experience terhadap Financial Management Behavior dengan Locus of Control sebagai Variabel Mediasi pada Pengguna Paylater

pada lingkup pendidikan yang dekat dan intens. Hal ini menyebabkan responden belum memiliki pengalaman keuangan yang banyak dan jarang menggunakan produk-produk lembaga keuangan. Implikasinya adalah meskipun responden memiliki pengalaman keuangan yang cukup yaitu pada kategori sedang, hal ini pada kenyataannya belum tentu diwujudkan dalam perilakunya sehingga tidak mampu mengubah atau memengaruhi perilaku keuangan menjadi lebih. Penelitian ini didukung oleh Safitri \& Kartawinata (2020).

\section{Pengaruh Locus of Control terhadap Financial Management Behavior}

Hasil penelitian tidak dapat membuktikan $\mathrm{H} 4$ karena dari hasil perhitungan menyatakan locus of control tidak terbukti memengaruhi financial management behavior. Hal tersebut menunjukkan bahwa responden penelitian yaitu pengguna paylater di Surabaya cenderung tidak memberikan reaksi pengendalian diri terhadap lingkungan sekitarnya dan melihat pandangan di masa yang akan datang sehingga tidak memengaruhi bagaimana responden membuat keputusan dan menyelesaikan masalah keuangan yang lebih baik. Hasil ini tidak sesuai dengan social learning theory yang menjelaskan bahwa terdapat empat konsep pokok yang mendasari seseorang dalam memilih perilaku yang dilakukan, yaitu situasi psikologis, potensi perilaku, nilai penguatan dan harapan (Rotter, 1966).

Hal ini terjadi karena 75,6\% responden merupakan perempuan, di mana meskipun pengendalian diri dari seorang wanita lebih tinggi namun dalam penerapan dalam kehidupan sehari-hari perempuan cenderung lebih konsumtif seiring dengan praktik belanja impulsif yang sering dilakukan dan banyaknya fitur-fitur belanja yang mudah dan menarik. Walaupun mereka telah memiliki keyakinan dengan pengendalian diri yang baik pada kenyataannya belum tentu diwujudkan dalam perilakunya sehingga tidak mampu mengubah atau memengaruhi perilaku keuangan menjadi lebih bertanggung jawab. Penelitian ini didukung oleh Prihartono \& Asandimitra (2018), Rahmawati \& Asandimitra (2020), Yanuar \& Asandimitra (2019), dan Ida \& Dwinta (2010).

\section{Pengaruh Financial Knowledge terhadap Financial Management Behavior dengan Mediasi Locus of Control}

Hasil sobel test menunjukkan locus of control tidak berhasil menjadi mediasi hubungan antara financial knowledge terhadap financial management behavior maka H5 ditolak. Hal ini menunjukkan locus of control pengguna paylater di Surabaya tidak memediasi hubungan antara financial management behavior yang dibentuk dari financial knowledge, meskipun seseorang mempunyai pengetahuan keuangan yang tinggi belum tentu membangun kontrol diri yang baik dalam perilaku pengelolaan keuangannya.

Uji hipotesis yang dilakukan sebelumnya telah mendapatkan hasil yaitu financial knowledge mampu memengaruhi perilaku pengelolaan keuangan yang lebih baik secara langsung tanpa melalui variabel mediasi yaitu locus of control. Selain itu locus of control justru tidak terbukti memengaruhi financial management behavior secara langsung karena walaupun responden telah memiliki pengendalian diri yang baik, mereka belum mampu menerapkannya secara maksimal. Sehingga hasil ini dapat dinyatakan peran mediasi locus of control untuk pengaruh variabel pengetahuan keuangan terhadap financial management behavior tidak dapat dibuktikan. Hasil ini didukung oleh penelitian Rahmawati \& Asandimitra (2020) dan Mien \& Thao (2006).

\section{KESIMPULAN}

Penelitian ini membuktikan financial knowledge berpengaruh terhadap financial management behavior, artinya seseorang dengan pengetahuan keuangan luas akan dapat menentukan keputusan keuangan dengan pertimbangan yang lebih baik sehingga akan dapat mengelola keuangan dengan lebih maksimal. Hasil lain menujukkan bahwa financial socialization, locus of control dan financial experience tidak terbukti memengaruhi financial management behavior. Selain itu locus of control sebagai mediasi juga tidak dapat memediasi hubungan financial knowledge terhadap financial management behavior. Hal ini terjadi karena responden penelitian mayoritas masih belum berada pada kondisi mandiri secara keuangan sehingga belum dapat mengambil keputusan secara mandiri, 
kurangnya pengalaman terkait lembaga keuangan serta responden belum mampu mengendalikan diri untuk mengutamakan kebutuhan dari pada keinginannya terlebih lagi dengan adanya kemudahan bertransaksi yang ditawarkan oleh penyedia $e$-wallet yaitu fitur paylater.

Pengguna fitur paylater khususnya di Kota Surabaya sebaiknya selalu meningkatkan pengetahuan keuangan yang mencakup beberapa hal yaitu simpanan/pinjaman, pengetahuan keuangan pribadi, investasi, dan asuransi. Pengetahuan keuangan ini bisa diperoleh melalui media-media yang menyediakan informasi tentang fitur-fitur paylater. OJK (Otoritas Jasa Keuangan) hendaknya mengedukasi masyarakat melalui sosialisasi secara berkala untuk meningkatkan pengetahuan keuangan sehingga masyarakat meningkatkan perilaku pengelolaan keuangan yang baik dalam rangka meningkatkan pertumbuhan ekonomi nasional. Penelitian selanjutnya disarankan untuk menggunakan model yang berbeda untuk meneliti tentang perilaku pengelolaan keuangan sehingga mampu menyajikan model yang lebih akurat, bisa dilakukan dengan menggunakan variabel lain antara lain jenis kelamin, usia, tingkat pendidikan, financial attitude, pendapatan, dan financial self-efficacy, serta melibatkan variabel mediasi lain seperti financial self-efficacy dan financial literacy. Penelitian selanjutnya juga dapat memperluas cakupan penelitian atau mencoba objek yang berbeda dengan penelitian ini, misalnya pada mahasiswa dan generasi milenial. Penyebaran kuesioner hendaknya lebih merata untuk hasil yang lebih maksimal, seperti menumpuknya pada karakteristik usia 15-24 tahun dan pekerjaan responden yaitu pelajar/ mahasiswa, yang seharusnya tidak berat dalam satu kategori saja. Hal ini diakibatkan karena penyebaran kuesioner hanya secara daring/online.

\section{DAFTAR PUSTAKA}

Ajzen, I. (1991). The Theory of Planned Behavior. Organizational Behavior and Human Decision Processes, 50, 178-211. https://doi.org/10.15288/jsad.2011.72.322

Ajzen, I. (2002). Perceived Behavioral Control, Self-Efficacy, Locus of Control, and The Theory of Planned Behavior. Journal of Applied Social Psychology, 32(4), 665-683. https://doi.org/10.1111/j.1559-1816.2002.tb00236.x

Ajzen, I. (2005). Attitudes, Personallity and Behavior. International Journal of Strategic Innovative Marketing (Vol. $3, \quad$ p. https://www.researchgate.net/publication/263228532_Atitudes_Personality_and_Behavior

Albeerdy, M. I., \& Gharleghi, B. (2015). Determinants of the Financial Literacy among College Students in Malaysia. International Journal of Business Administration, 6(3), 15-24. https://doi.org/10.5430/ijba.v6n3p15

Ameliawati, M., \& Setiyani, R. (2018). The Influence of Financial Attitude, Financial Socialization, and Financial Experience to Financial Management Behavior with Financial Literacy as the Mediation Variable. International Conference on Economics, Business and Economic Education, 2018, 811-832. https://doi.org/10.18502/kss.v3i10.3174

bi.go.id. (2020). Apa Itu Uang Elektronik. (https://www.bi.go.id/id/edukasi/Pages/Apa-itu-UangElektronik.aspx. diakses pada 12 Oktober 2020)

Churchill, G. A., \& Moschis, G. P. (1979). Television and Interpersonal Influences on Adolescent Consumer Learning. Journal of Consumer Research, 6(1), 23-35. https://doi.org/10.1086/208745

Darmawan, A., Suyoto, Widhiandono, H., Utami, N. H., Razak, A. A. Z. A., \& Ab Wahid, H. (2018). The Effect of Financial Literacy, Financial Experience, and Locus of Control Towards Financial Management Attitude and Family Investment Planning Behavior. Proceedings International Conference of Business, Accounting and Economic (ICBAE UMP 2018), April, 
Vicky Pradita Dewanti \& Nadia Asandimitra. Pengaruh Financial Socialization, Financial Knowledge, Financial Experience terhadap Financial Management Behavior dengan Locus of Control sebagai Variabel Mediasi pada Pengguna Paylater

206-215. https://doi.org/10.13140/RG.2.2.15088.30722

Ida, \& Dwinta, C. Y. (2010). Pengaruh Locus of Control, Financial Knowledge, Income terhadap Financial Management Behavior. In Jurnal Bisnis Dan Akuntansi (Vol. 12, Issue 3, pp. 131144). https://doi.org/10.34208/jba.v12i3.202

Kholilah, N. Al, \& Iramani, R. (2013). Studi Financial Management Behavior pada Masyarakat Surabaya. Journal of Business and Banking, 3(1), 69. https://doi.org/10.14414/jbb.v3i1.255

kompas.com. (2015). OJK: Orang Indonesia Makin Konsumtif. (https://money.kompas.com/read/2015/08/08/110746226/OJK.Orang.Indonesia.Makin.Konsum tif. diakses pada 23 Oktober 2020)

Kusnandar, V. B. (2019). Berapa Transaksi Uang Elektronik di Indonesia? Databoks.Katadata.Co.Id. (https://databoks.katadata.co.id/datapublish/2019/11/07/berapa-transaksi-uang-elektronik-diindonesia. diakses pada 11 November 2020)

Lidwina, A. (2019). Fitur Paylater OVO Paling Banyak Digunakan Sepanjang 2019. Databoks.Katadata.Co.Id. (https://databoks.katadata.co.id/datapublish/2019/11/28/fiturpaylater-ovo-paling-banyak-digunakan-sepanjang-2019. diakses pada 9 November 2020)

Mason, C. L. ., \& Wilson, R. M. S. (2000). Conceptualising Financial Literacy. Journal of Consumer Affairs, $7, \quad 1-24$. https://www.researchgate.net/publication/28576413_Conceptualising_Financial_Literacy

Mien, N. T. N., \& Thao, T. P. (2006). Factors Affecting Personal Financial Management Behaviors: Evidence from Vietnam. Proceedings of the Second Asia-Pacific Conference on Global Business, Economics, Finance and Social Sciences (AP15Vietnam Conference), 47(3), 327328. https://doi.org/10.1161/01.HYP.0000200705.61571.95

Pradiningtyas, T. E., \& Lukiastuti, F. (2019). Pengaruh Pengetahuan Keuangan dan Sikap Keuangan terhadap Locus of Control dan Perilaku Pengelolaan Keuangan Mahasiswa Ekonomi. Jurnal Minds: Manajemen Ide Dan Inspirasi, 6(1), 96. https://doi.org/10.24252/minds.v6i1.9274

Prihartono, M. R. D., \& Asandimitra, N. (2018). Analysis Factors Influencing Financial Management Behaviour. International Journal of Academic Research in Business and Social Sciences, 8(8), 308-326. https://doi.org/10.6007/ijarbss/v8-i8/4471

Pritazahara, R., \& Sriwidodo, U. (2015). Pengaruh Pengetahuan Keuangan dan Pengalaman Keuangan terhadap Perilaku Perencanaan Investasi Dengan Self Control sebagai Variabel Moderating. Jurnal Ekonomi dan Kewirausahaan, 15(1), 28-37. http://ejurnal.unisri.ac.id/index.php/Ekonomi/article/view/1010

Purwidianti, W., \& Mudjiyanti, R. (2016). Analisis Pengaruh Pengalaman Keuangan dan Tingkat Pendapatan terhadap Perilaku Keuangan Keluarga di Kecamatan Purwokerto Timur. Benefit: Jurnal Manajemen dan Bisnis, 1(2), 141. https://doi.org/10.23917/benefit.v1i2.3257

Purwidianti, W., \& Tubastuvi, N. (2019). The Effect of Financial Literacy and Financial Experience on SME Financial Behavior in Indonesia. Jurnal Dinamika Manajemen, 10(1), 40-45. https://doi.org/10.15294/jdm.v10i1.16937

Rahmawati, N. W., \& Asandimitra, N. (2020). Analisis Faktor yang Memengaruhi Financial Management Behavior dengan Mediasi Locus of Control. Jurnal Ilmu Manajemen, 8(2), 549563. https://jurnalmahasiswa.unesa.ac.id/index.php/jim/article/view/33265 
Ramadhan, A. Y., \& Asandimitra, N. (2019). Determinants of Financial Management Behavior of Millenial Generation in Surabaya. Jurnal Minds : Manajemen Ide Dan Inspirasi, 6(2), 129-144. https://doi.org/10.24252/minds.v6i2.9506

Rizkiawati, N. L., \& Asandimitra, N. (2018). Pegaruh Demografi, Financial Knowledge, Financial Attitude, Locus of Control dan Financial Self-Efficacy terhadap Financial Management Behavior Masyarakat Surabaya. Jurnal Ilmu Manajemen, 6(3), 93-107. https://jurnalmahasiswa.unesa.ac.id/index.php/jim/\%20article/view/23846

Rohmatillah, H. (2019). Bijak dalam Menggunakan Aplikasi Paylater. Kompasiana.Com. (https://www.kompasiana.com/hildarohmatillah3828/5db1622f0d82304946177b13/bijakdalam-menggunakan-aplikasi-paylater. diakses pada 12 Desember 2020)

Rotter, J. B. (1966). Generalized Expectancies for Internal Versus External Control of Reinforcement. Psychological Monographs: General and Applied, 80(1), 1-28. https://doi.org/10.1037/h0092976

Safitri, A., \& Kartawinata, B. R. (2020). Pengaruh Financial Socialization dan Financial Experience Terhadap Financial Management Behavior ( Studi pada Wanita Bekerja di Kota Bandung ). Jurnal Ilmu Keuangan Dan Perbankan (JIKA), 9(2). https://ojs.unikom.ac.id/index.php/jika/article/view/2987/1997

Sina, P. G., \& Noya, A. (2012). Pengaruh Kecerdasan Spiritual terhadap Pengelolaan Keuanagan Pribadi. Junal Manajemen, 11(2), 171-188. https://www.neliti.com/publications/112901/pengaruh-kecerdasan-spiritual-terhadappengelolaan-keuangan-pribadi

Sobaya, S., Hidayanto, M. F., \& Safitri, J. (2016). Pengaruh Literasi Keuangan dan Lingkungan Sosial Terhadap Perencanaan Keuangan Pegawai di Universitas Islam Indonesia Yogyakarta. Madania, 20(01), 1-14. https://doi.org/10.29300/madania.v20i1.90

Sundarasen, S. D. D., Rahman, M. S., Othman, N. S., \& Danaraj, J. (2016). Impact of Financial Literacy, Financial Socialization Agents, and Parental Norms on Money Management. Journal of Business Studies Quarterly, 22(12), 4312-4315. https://www.researchgate.net/publication/315816479_Impact_of_Financial_Literacy_Financial _Socialization_Agents_and_Parental_Norms_on_Money_Management

Wahyunik, S. (2019). Data BI, 258 Ribu Warga Jember Bertransaksi Pakai Uang Elektronik, Terbanyak Kedua setelah Surabaya. (https://surabaya.tribunnews.com/2019/08/27/data-bi-258ribu-warga-jember-bertransaksi-pakai-uang-elektronik-terbanyak-kedua-setelah-surabaya. diakses pada 11 Desember 2020)

Ward, S. (1978). Contributions of Socialization Theory to Consumer Behavior Research. Journal of Consumer Research, 1(2), 1-14. https://doi.org/10.1086/208584

Yanuar, A., \& Asandimitra, N. (2019). Determinants of Financial Management Behavior of Millennial Generation in Surabaya. Jurnal Minds: Manajemen Ide dan Inspirasi, 6(2), 129. https://doi.org/10.24252/minds.v6i2.9506 